\title{
IMPLEMENTASI DATATABLES SERVER-SIDE UNTUK MEMPERCEPAT LOAD HALAMAN PADA APLIKASI E-COMMERCE
}

\author{
Ardian Dwi Praba' ${ }^{1)}$, Maryanah Safitri' ${ }^{2)}$ Faridi $^{3)}$ \\ ${ }^{1}$ Program Studi Sistem Informasi, Universitas Nusa Mandiri, Jln. Jatiwaringin Raya No.02 Jakarta Timur \\ 2 Program Studi Teknik Informatika, Universitas Nusa Mandiri, Jln. Jatiwaringin Raya No.02 Jakarta Timur \\ ${ }^{3}$ Program Studi Teknik Informatika, Universitas Muhammadiyah Tangerang, Jl. Perintis Kemerdekaan I \\ Babakan No. 33 Cikokol, Tangerang, Indonesia \\ Co Responden Email : ${ }^{1 *}$ ardian.ddw@ nusamandiri.ac.id, ${ }^{2}$ maryanah.msf@ nusamandiri.ac.id, \\ 3faridi@umt.ac.id
}

Article history

Received April 14, 2021

Revised June 12, 2021

Accepted June 20, 2021

Available online June 20, 2021

Keywords

Bigdata,

datatable,

website,

serverside,

clientside

\begin{abstract}
Large amounts of data are a new challenge in Industry 4.0 at this time, where the data must be accessed and processed quickly by computers. Large data causes the data presentation process to be very long because all data must be processed in one go. So that we need a special technique so that the presentation of information runs quickly even though the data that must be subject to the number is very large. In general, the website requsets the server, if the server data system exists, the data will be sent by the server to the client according to the number of existing data processes. The more data sent by the server, the longer it will take the client to display existing data. In this research, we will try to use server-side processing datatables where all processes will be carried out on the server side and data is sent periodically to the client according to the input request or keyword. The conclusion of this research is that the data speed using server side processing techniques is $79 \%$ better than client side processing.
\end{abstract}

\section{Riwayat}

Diterima 14 April 2021

Revisi 12 Juni 2021

Disetujui 20 Juni 2021

Terbit 20 Juni 2021

Kata Kunci

Bigdata,

datatable,

website,

serverside,

clientside

\begin{abstract}
Abstrak
Data dalam jumlah besar merupakan tantangan baru pada industri 4.0 saat ini, dimana data tersebut harus bisa ditampilkan dan diolah secara cepat oleh komputer. Data yang besar menyebabkan proses penyajian data menjadi sangat lama karena semua data harus ditampilkan dalam sekali proses. Sehingga diperlukan sebuah teknik khusus agar penyajian informasi bisa berjalan dengan cepat walaupun data yang harus ditampilkan jumlanya sangat banyak. Secara Umum website melakukan proses request kepada server, jika pada sisi server data tersebut ada, maka data akan dikirimkan oleh server kepada client sesuai dengan jumlah data yang ada. Semakin banyak data yang dikirim oleh server maka akan semakin lama waktu yang dibutuhkan client dalam menampilkan data yang ada. Penelitian ini menggunakan datatables server-side processing, dimana semua proses dilakukan pada sisi server dan data dikirimkan secara berkala kepada client sesuai dengan permintaan atau kata kunci yang dimasukan. Hasil dari penelitian ini yaitu kecepatan pemrosesan data dengan menggunakan teknik server-side processing $79 \%$ lebih baik dibandingkan dengan client-side processing.
\end{abstract}

\section{PENDAHULUAN}

Saat ini semenjak maraknya penggunaan slogan "paperless" menjadikan permasalah baru bagi dunia digital. Data digital semakin bertumpuk, dari hari ke hari database berjumlah ratusan, ribuan bahkan jutaan. Para ahli, pakar maupun organisasi mencari alternatif dan pendekatan terbaik untuk mengelola data besar. Tren penyajian 
data yang paling banyak digunakan para developer adalah library datatable. Datatable menggunakan tipe koneksi halfduplex yaitu dua arah namum tidak bisa bersamaan (Husen, 2018). Datatable merupakan library jquery javascript yang bertujuan untuk manipulasi data yang panjang menjadi data pendek, selain itu mempunyai fitur seperti pencarian, halaman, sorting dan tampilan data yang rapi, interaktif dan responsive (Alhaq, 2021). Namun seiring dengan waktu, datatable menuai kontroversi bagi web developer. Penggunaan datatable menyebabkan kinerja suatu web menjadi lambat, hal ini dikarenakan datatable meload semua record yang ada pada suatu table dalam database. Ketika data masih sedikit tidak ada permasalahan, kinerja penyajian data berjalan normal. Namun ketika data besar hal ini menjadi kendala dan mengurangi kinerja sehingga performa web menjadi sangat lama dalam menampilkan data (D. Gope, 2017). Untuk mengatasi permasalahan tersebut, maka dilakukan percobaan penerapan teknik server-side processing sehingga dengan menitikberatkan semua proses pada sisi server akan membuat proses load data pada sisi client menjadi ringan dan cepat. Karena dengan teknik ini data besartidak akan di load semua secara langsung, melainkan dibatasi oleh server berdasarkan dengan request yang dilakukan oleh client. Dengan demikian berapapun jumlah record yang akan disajikan tidak akan menjadi kendala lagi. Maka pada penelitian ini dilakukan percobaan untuk menguji kinerja penggunaan teknik server-side processing pada penyajian big data sehingga kinerja web lebih optimal.

\section{KAJIAN LITERATUR}

\section{A. Datatable}

Datatable merupakan plugin Jquery yang bersifat opensource. Datatable mengkonversi tampilan table html menjadi format dengan tampilan datatable dengan antarmuka yang intuitif. Plugin Datatable menyediakan fitur penting yang mendukung penyajian data. Gitur tersebut meliputu pencarian data dengan menggunakan keyword, paginasi, filter jumlah baris data yang ditampilkan per halaman dan juga sorting serta masih banyak beberapa fitur yang bisa dimunculkan pada datatable (Alhaq \& Sujarwo, 2021)

\section{B. Big Data}

Big Data bukan hanya istilah yang mengacu pada volume data, tetapi juga mengacu pada kecepatan data, dan variasi yang jarang terstruktur, melainkan tidak terstruktur. Volumenya berada dalam kisaran banyak Terabyte ke Petabyte. Volume menyajikan tantangan paling cepat bagi TI konvensional struktur, panggilan untuk penyimpanan yang dapat diskalakan, dan pendekatan terdistribusi untuk kueri. Kecepatan data mengacu pada tingkat peningkatan di mana data mengalir ke organisasi dan kecepatan umpan balik, mengambil data dari masukan hingga keputusan (Ghandour, 2015).

\section{PHP}

PHP adalah pemrograman interpreter yaitu proses penerjemahan baris kode sumber menjadi kode mesin yang dimengerti komputer secara langsung pada saat baris kode dijalankan. PHP (PHP: Hypertext Preprocessor) adalah sebuah bahasa pemrograman yang perintahnya dilaksanakan server dan kemudian hasilnya ditampilkan pada komputer client. PHP juga merupakan HTML embedded, yaitu sintaks PHP yang dituliskan bersamaan dengan sintaks HTML. Jadi PHP dan HTML adalah sinergi dua bahasa pemrograman yang saling menguatkan. Walaupun sebagian orang berpendapat HTML bukan sebuah bahasa pemrograman (Haviluddin, 2016).

\section{JavaScript}

JavaScript merupakan bahasa script yang dipakai untuk menciptakan halaman web yang dapat berinteraksi dengan pengguna dan dan dapat merespon event yang terjadi pada halaman. JavaScript merupakan perekat yang menyatukan halaman-halaman web (Sianipar, 2015). Saat ini hampir semua aplikasi berbasis web menggunakan javascript untuk mendukung proses bisnis yang ada pada sebuah aplikasi web. Saat ini ada banyak library javascript yang tersedia diinternet dan tersedia secara gratis untuk pengembangan sebuah aplikasi berbasis web. Diantara library yang banyak digunakan adalah Ajax yang diperkenalkan oleh Jesse James Garret dari 
Adaptive Path pada tahun 2005. Ia mendeskripsikan bagaimana mengembangkan web yang berbeda dengan metode tradisional (Suryaningrat, 2016)

\section{E. Mysql}

Pada perkembangannya, MYSQL disebut juga SQL yang merupakan singkatan dari Structured Query Language. SQL merupakan Bahasa terstruktur yang khusus digunakan untuk mengolah database. SQL pertama kali didefinisikan oleh American National Standards Institute (ANSI) pada tahun 1986. MYSQL adalah sebiah system manajemen database yang setbersifat open source. MYSQL merupakan sistem manajemen database yang bersifat relational. Artinya, data yang dikelola dalam database yang akan diletakkan pada beberapa tabel yang terpisah sehingga manipulasi data akan jauh lebih cepat (Novendri, 2019). Mysql adalah salah satu database yang sangat terkenal dan banyak digunakan oleh para pengembang karena kecepatan dan fitur yang lengkap serta gratis.

\section{F. Literatur Review}

Penelitian yang pertama (Sulastri, Rahmatulloh, \& Hidayat, 2019) menunjukan hasil pengujian tools menggunakan JMeter terhadap client-side processing dan server-side processing didapat presentase $98,6 \%$ lebih cepat server-side processing dibandingkan client-side processing. Sementara pada penggunaan memory server-side processing lebih kecil 99,6\% dibandingkan dengan clientside processing. Penelitian yang kedua (Rianto, 2019) menunjukan bahwa menggunakan pemrosesan sisi server, paging, pencarian, pemesanan dilakukan dari server di mana mesin SQL atau sejenisnya dapat mengambil tindakan pada data yang besar dan cepat. Sehingga akan menghasilkan permintaan ajax yang dibuat dengan permintaan data yang diperlukan, maka menggunakan data server-side akan lebih ringan dalam permintaan dan pemrosesan data. Pada penelitian yang ketiga (Alhaq \& Sujarwo, 2021) menunjukan bahwa Dengan menggunakan teknik server-side processing pada datatable, dapat mengurangi load time pada sebuah halaman. Hal tersebut karena beban yang ditanggung oleh client-side tidak terlalu besar dan tidak perlu waktu lama untuk menunggu respon server saat pertama kali memuat halaman.

\section{G. Serverside Processing}

Pemrosesan sisi server berperan ketika memiliki jumlah data yang sangat besar, dimana data tersebut ingin di tampilkan pada sebuah tabel. Pada tahap ini proses pengiriman data ke klien menggunakan javascript untuk mendapatkan hasil yang bagus pada hasil akhir. Pada model pemrosesan sisi server, semua permintaan, pencarian, dan lain-lain yang berasal dari data akan diserahkan ke server, dengan menggunakan mesin pengelolaan database yang ada. Setiap halaman data akan membuat permintaan ajax ke server. Meskipun setiap permintaan ajax akan membutuhkan waktu sepersekian detik untuk menyelesaikannya (Rianto, 2019)

\section{METODE PENELITIAN}

A. Langkah-langkah pengujian

Pada pengujian ini penulis menggunakan pengujian sebanyak 3 kali pengujain dengan jumlah record yang berbeda seperti pada table $\mathrm{x}$ di bawah ini

Tabel 1. Jumlah dataset dan metode yang digunakan

\begin{tabular}{|l|l|l|l|}
\hline Dataset & Pengujian 1 & Pengujian 2 & Pengujian 3 \\
\hline $\begin{array}{l}\text { Client- } \\
\text { side }\end{array}$ & 10.000 & 50.000 & 100.000 \\
\hline $\begin{array}{l}\text { Server- } \\
\text { side }\end{array}$ & 10.000 & 50.000 & 100.000 \\
\hline
\end{tabular}

B. Rancangan Pengujian

Rancangan kinerja pengujian client-side dan server-side dilakukan dengan menampilkan data dalam jumlah banyak dengan tiga kali pengujian dengan jumlah record yang berbeda pada masig-masing pengujian. Pengukuran dilakukan dengan menghitung waktu yang dibutuhkan oleh aplikasi dalam menampilkan data.

Pada awal pengujian data akan ditampilkan dengan mengguakan teknik client-side dan akan diukur waktu loading data sampai selesai, selanjutnya pengujian akan dilakukan dengan menggunakan teknik serverside dan akan diukur waktu loading data sampai selesai. Dari hasil pengukuran diatas maka akan terlihat teknik mana yang akan 
menghasilkan waktu yang lebih cepat dalam menampilkan data dalam aplikasi.

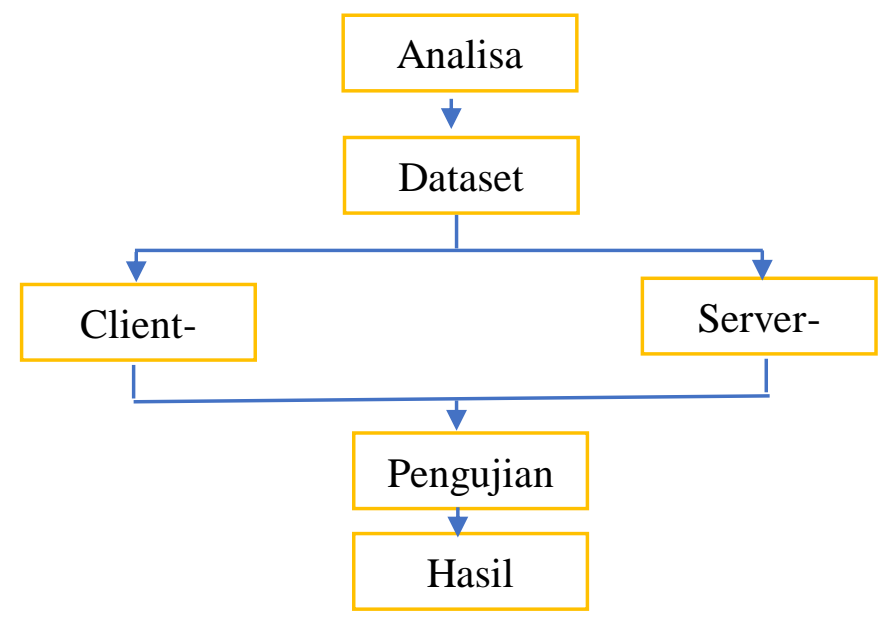

Gambar 1. Alur Pengujian Data

\section{HASIL DAN PEMBAHASAN}

Tahap implementasi sistem (system implementation) merupakan tahap meletakkan sistem supaya siap untuk diopersikan. Tahap ini termasuk juga kegiatan menulis kode program jika tidak digunakan paket perangkat lunak aplikasi .Implementai juga merupakan penerapan dari elemen-elemen yang telah didesain dalam bentuk pemograman untuk menghasilkan suatu tujuan yang dibuat berdasarkan kebutuhan.

Pada pengujian ini penulis menggunakan tools yang sama untuk membandingkan kecepatan dalam antara client-side dan juga server-side dalam menampilkan data dalam jumlah yang sangat banyak. Spesifikasi hardware dan system operasi yang digunakan digunakan pada penelitian ini sebagai berikut:.

Intel Core i3-4310@3.40 GHz

Ram 4 GB

System Type 64-bit

Sistem Operasi Windows 10

Server Apache

Database MariaDB

Denngan menggunakan tools yang sama diharapkan hasil yang diperoleh dari pengujian ini bisa lebih komperhensif dibandingkan penulis melakukan pengujian dengan tools yang berbeda. Untuk menampilkan data kita harus menuliskan url atau alamat situs yang akan dijadikan sebagai pengujian. Disini alamat yang digunakan adalah http://127.0.0.1/uji.

Dalam penelitian ini penulis melakukan perbandiangan dari kedua metode yaitu clienside dan server-side. Pengukuran dilakukan dengan menghitung jumlah waktu yang dibutuhkan oleh masing-masing metode dengan jumlah data yang berbeda. Semakin sedikit waktu yang dibutuhkan untuk menampilkan data maka akan semakin bagus. Pengukuran dilakukan dengan menambahkan baris kode dari pemrograman PHP dimasingmasing halaman pengujian. Baris kode yang digunakan untuk menghitung kecepatan sebuah halaman dalam menampilkan data antara client-side dan server-side sebagai berikut:

\section{$<$ ?php}

\$starttime $=$ explode(' ', microtime ()$)$;

$\$$ starttime $=\$$ starttime $[1]+\$$ starttime $[0] ;$

$\$$ load $=$ microtime () ;

\$loadtime = explode(' ', microtime());

\$loadtime $=$ \$loadtime[0]+\$loadtime[1]-

\$starttime;

echo "Page generated in

".number_format(\$load,2)." seconds";

echo "Peak memory usage: ".round(memory_get_peak_usage()/1048576,

2), "MB"; ?>

Berikut ini pengujian yang dilakukan dengan menggunakan tiga jenis dataset yang berbeda dengan masing-masing pengujian mulai dari 10.000, 50.000. 100.000 record data.

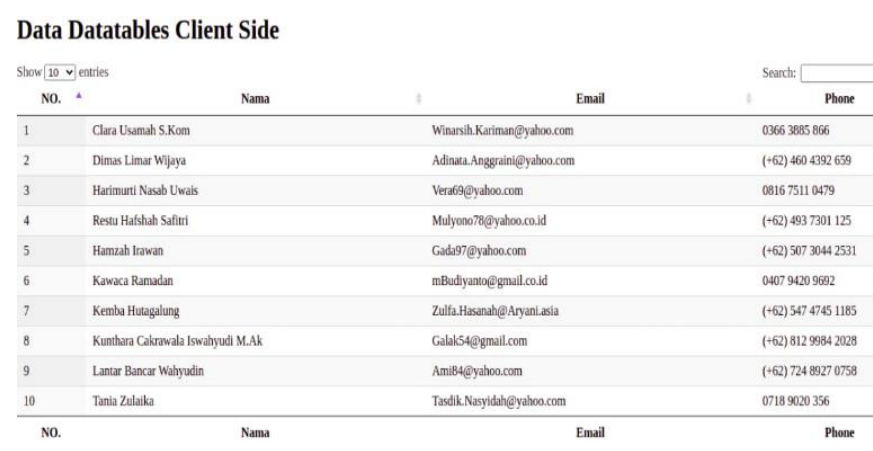

Gambar 2. Pengujian client-side

Pengujian dilakukan dengan menggunakan metode client-side, pada pengujian ini browser menampilkan data dengan cepat saat jumlah record masih sedikit, namun semakin banyak jumlah record maka 
browser menjadi semakin lambat dan bisa sampai melebihi 30 detik. Hal ini terjadi karena client-side mengambil semua data yang ada untuk selanjutnya ditampilkan dalam browser sehingga semakin banyak data maka semakin lama waktu yang dibutuhkan.

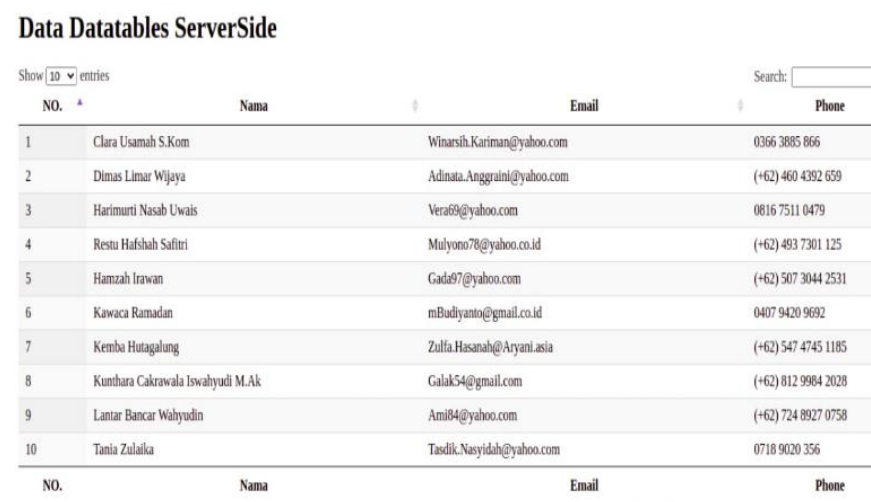

Gambar 3 . Pengujian dengan server-side

Pengujian dilakukan dengan menggunakan metode server-side, pada pengujian ini browser menampilkan data dengan cepat pada saat jumlah data masih sedikit. Namun dengan pengujian data yang banyak hal ini tidak teralalu banyak berpengaruh pada browser dalam menampilkan data dengan waktu yang sangat cepat. Hal ini dikarenakan server-side hanya memanggil sebagian data dari seluruh data yang ada sehingga berapapun jumlah record yang ingin ditampilkan tidak akan menjadi masalah.

Table 2. Waktu yang dibutuhkan browser dalam menampilkan data

\begin{tabular}{|c|c|c|c|}
\hline Data & $\mathbf{1 0}$ ribu & $\mathbf{5 0}$ ribu & $\mathbf{1 0 0}$ ribu \\
\hline $\begin{array}{c}\text { Server- } \\
\text { side }\end{array}$ & $0,0031 \mathrm{~s}$ & $0,0055 \mathrm{~s}$ & $0,033 \mathrm{~s}$ \\
\hline $\begin{array}{c}\text { Client- } \\
\text { side }\end{array}$ & $0,2404 \mathrm{~s}$ & $3,8018 \mathrm{~s}$ & $3,939 \mathrm{~s}$ \\
\hline
\end{tabular}

Berdasarkan tabel diatas maka bisa dijelaskan bahwa:

1. Percobaa dengan 10 ribu record pada server-side membutuhkan waktu 0,0031s sedangkan pada client-side membutuhkan waktu $0,2404 \mathrm{~s}$ terdapat selisih $0,2373 \mathrm{~s}$ lebih cepat server-side.

2. Percobaa dengan 50 ribu record pada server-side membutuhkan waktu 0,0055 s sedangkan pada client-side membutuhkan waktu 3,8018s terdapat selisih $3,7963 \mathrm{~s}$ lebih cepat server-side.

3. Percobaa dengan 100 ribu record pada server-side membutuhkan waktu $0,033 \mathrm{~s}$ sedangkan pada client-side membutuhkan waktu 3,939s terdapat selisih 3,906s lebih cepat server-side

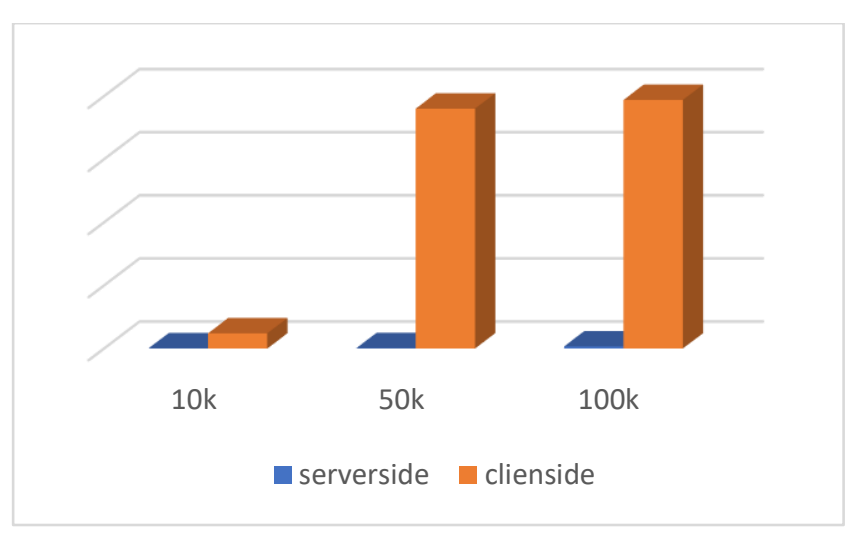

Gambar 4. Diagram hasil pengujian

KESIMPULAN

Dari penelitian yang sudah dilakuan terbukti bahwa serverside lebih unggul dibandingkan dengan clientside dalam menampilkan data dalam jumlah yang besar. Dalam sebuah aplikasi berbasis web, maka menampilkan data dalam jumlah besar ada sebuah tantangan tersendiri sehingga aplikasi harus mampu menentukan metode yang paling tepat dalam melayani data dalam jumlah yang besar. Sebuah sistem membutuhkan kecepatan dalam pemrosesan, sistem yang berjalan dalam waktu lama akan mengalami penurunan kinerja karena data yang dimiliki semakin besar. Pengimplementasian serverside datatables processing menjadi salah satu solusi untuk sebuah aplikasi dalam menampilkan data sehingga walaupun data yang akan ditampilkan sangat banyak tidak terlalu berpengaruh terhadap aplikasi karena data akan di tampilkan secara berkala sesuai dengan kebutuhan pengguna. Dengan demikian untuk pembuatan aplikasi berbasis 
web, maka serverside menjadi pilihan terbaik baik untuk data yang kecil maupun data dalam ukuran yang sangat besar.

\section{REFERENSI}

Alhaq, M. B., \& Sujarwo, A. (2021). UTILISASI PENGOLAHAN PEMROSESAN DATA UNTUK MENINGKATKAN PERFORMA APLIKASI, 2(1). Retrieved from https://journal.uii.ac.id/AUTOMATA/ar ticle/view/17358/10892

D. Gope, D. J. (2017). Architectural support for server-side PHP processin. Annual International Symposium on Computer Architecture.

Ghandour, A. (2015). BIG DATA DRIVEN E-COMMERCE ARCHITECTURE. International Journal of Economics.

Haviluddin, A. T. (2016). Aplikasi Program PHP \& Mysql. Samarinda: Mulawarman University Press.

Husen, A. R. (2018). IMPLEMENTASI KOMUNIKASI FULL DUPLEX MENGGUNAKAN WEB. Jurnal SIMETRIS.

Novendri, M. S. (2019). APLIKASI INVENTARIS BARANG PADA MTS NURUL ISLAM . Lentera Dumai.

Rianto, R. (2019). Implementasi DataTables Sever-Side Processing Pada Aplikasi
Surat-Surat dan Iventaris Lab STTA

Yogyakarta. Jurnal Dinamika Informatika, 8(1), 15-29. Retrieved from

https://www.researchgate.net/profile/Ria nto-Rianto-

2/publication/333161879_Implementasi

_DataTables_Sever-

Side_Processing_Pada_Aplikasi_SuratSurat_dan_Iventaris_Lab_STTA_Yogya karta/links/5cde592fa6fdccc9ddb56346/ Implementasi-DataTables-Sever-SideProcessing-Pada-Aplikasi-Surat-Suratdan-Iventaris-Lab-STTA-

Yogyakarta.pdf

Sianipar, R. H. (2015). Pemrograman Javascript. BANDUNG: Informatika.

Sulastri, H., Rahmatulloh, A., \& Hidayat, D.

K. (2019). SERVER-SIDE PROCESSING TECHNIQUES FOR OPTIMIZING THE SPEED. Jurnal Pilar Nusa Mandiri, 15(1), 47-52.

Retrieved from http://ejournal.nusamandiri.ac.id/index.p hp/pilar/article/view/62/56

Suryaningrat, I. G. N. J. (2016). Perancangan Sistem Informasi Wisata Kuliner Berbasis Web Dengan Menggunakan Ajax dan Code Igniter. Jurnal Sistem Dan Informatika, 10(2), 1-8. Retrieved from https://jsi.stikombali.ac.id/index.php/jsi/article/view/52 